\title{
The effectiveness of communication interdependence between teachers, parents, accessors, and entrepreneurs affecting the work and entrepreneurial skills of vocational high school students
}

\author{
Rosmawaty Hilderiah Pandjaitan *, Elena Shinta Maharani Hutajulu \\ Master of Communication Sciences, Universitas Mercu Buana. \\ Jl. Meruya Selatan, Kembangan, Jakarta Barat 11650, Indonesia. \\ * Corresponding Author. Email: bundarossa@mercubuana.ac.id
}

\section{ARTICLE INFO}

\section{Article History}

Received:

1 December 2020;

Revised:

19 December 2020;

Accepted:

19 March 2021;

Available online:

30 July 2021

\section{Keywords}

Communication interdependency; Vocational High

School

\begin{abstract}
Quantitative type research with survey method of 372 respondents, taking research objects in SMKN 7 Tangerang Regency. Mixing Theory System (Bertalanfy), The Theory Open System (Shawn Fanning, 1999), and Social System Theory (Nikias Luhmann, 1987). The goal is to describe the model, quantity percentage, and factors that affect the effectiveness of communication interdependence between teachers, parents, accessors, and entrepreneurs affecting vocational high school students' work and entrepreneurial skills (SMKN 7 Tangerang Regency in Industrial Era 4.0). As a method of data analysis, used criterion-related validity test, with predictive validity form, using product-moment correlation technique. Test reliability with Cronbach's Alpha formula, SPSS 24, also conducted Pearson's Correlation Test, "F" test, and "T" test. The results are: 1.) Many factors that affect the effectiveness of interdependence of educational communication at this school in the industrial era 4.0. Among them are education knowledge, communication skills (multiple contingencies), communication behavior control (flexible and creative), and emotional communication (adaptable); 2.) Only interdependence of communication between students and entrepreneurs rated $100 \%$ effective towards work and entrepreneurial skills at SMKN 7 Kabupaten Tangerang students in the industrial era is 4.0 .
\end{abstract}

This is an open access article under the CC-BY-SA license.

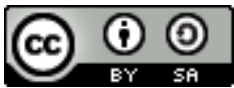

How to cite:

Pandjaitan, R. H., \& Hutajulu, E. S. M. (2021). The effectiveness of communication interdependence between teachers, parents, accessors, and entrepreneurs affecting the work and entrepreneurial skills of vocational high school students. Jurnal Pendidikan Vokasi, 11(1), 33-46. https://doi.org/10.21831/jpv.v11i1.35876

\section{INTRODUCTION}

According to the Bertalanfy (2009) sect system quoted by O'Hair et al. (2009), each organization has other needs, shortcomings, and features, which are interconnected. That is why if one part is damaged, then the entire system will be affected. So there is the concept of "interdependence," which gives birth to the concept of "synergy," which shows the combination and integration of talents, power, ability, and knowledge of its members, as well as the dynamics of communication that are important factors in order to be able to adapt to the environment. So, according to Bertalanfy, to organize to learn, be creative, and adapt to environmental changes, it takes a combination and integration of talents, power, ability, knowledge, and communication dynamics with its members. So it could be that a person is slow in learning and less creative due to a lack of a combination of talent, power, ability, knowledge, and interaction or communication with each other (Ref. Figure 1.) 
Likewise, according to Fanning (1999) that quoted by O'Hair et al. (2009), in the theory of the Open System, which is relevant and the continuation of the theory of the Bertalanfy school system, both organizations and organisms, develop themselves and groups by inviting experts from outside. Whether it's discussing the latest technology or discussing new ideas, encouraging their members to pursue higher degrees, work spirit, and the ability to work with people outside the organization. In addition, the open system also values the cultural diversity of its members and considers feedback to be an element of communication (Ref. Figure 2.).

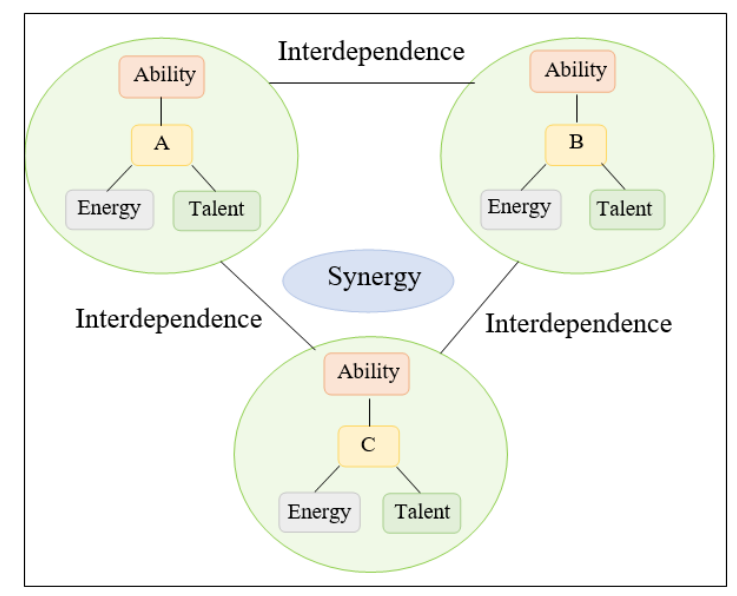

Figure 1. Systems Theory Model (Bertalanfy)

(Source: O’Hair et al., 2009)

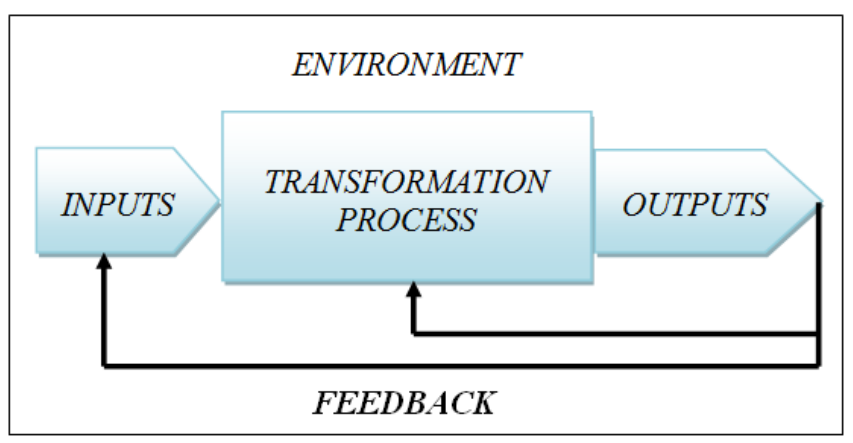

Figure 2. Open System Schematic

(Source: O’Hair et al., 2009)

The same thing was said by Luhmann (2001), in the theory of the social system, communication is a fundamental element of society produced by society, and each communication should consider how communication was received. In Luhamann's language is called "double contingency." But Luhamann also acknowledged that the acceptance of the communication itself also influenced the recipient's estimation of the communicator, so there was a circle of dependency between the receiver and the communicator. In addition, according to Luhamann that quoted by Ritzer and Goodman (2008), communication is necessary because each organism has a different set of norms, and since information can be communicated in a number of ways, it is unlikely that a person will choose one way only. Luhamann also acknowledged that communication could be disconnected, and in order not to break up, structures must be developed. Obviously, this theory carries the importance of people interacting or communicating with each other as a way of learning and being able to be creative. Does this theory also apply in the educational communication system at Vocational High School (SMK)?

This question arises given the high open unemployment rate (TPT) as of August 2017, of 7 million people, the largest of the vocational school graduates, about $11.24 \%$, as reported from Deny 
(2018) in Liputan6.com who wrote that data from the Central Bureau of Statistics (BPS). Of the 7.04 million unemployed people, the majority are Vocational High School (SMK) graduates, namely around $11.41 \%$. Meanwhile, from SMA 8.29\%, from SMP 5.54\%, from SD 2.62\%, from a diploma I / II / III at $6.88 \%$, and polytechnic at $5.18 \%$.

Whereas according to Government Regulation No. 29 of 1990, the vocational education system must produce graduates who can quickly adjust to the needs of the world of work and have work-ready competencies and entrepreneurship. But the facts are different. Is it possible that the system of interdependence and communication between schools (teachers and students) with parents, and the assessment of Professional Certification Bodies (LSP), as well as business and industrial actors or entrepreneurs (DU/DI) as external environments as well as users of Vocational High School (SMK) graduate output is no longer effective, so many vocational school graduates are difficult to work and entrepreneurial?

The characteristics of vocational education (vocational education) to be able to answer industry challenges 4.0., described by Bukit (2014), must have characteristics oriented towards individual performance in the world of work, specific justification on real needs in the field, the curriculum focuses on psychomotor, affective, and cognitive aspects, and the benchmarks of success are not only limited in schools. Still, they must also have sensitivity to the development of the world of work, thus requiring adequate means and infrastructure, and community support. According to Rawi (2013), it should focus on providing skilled labor in various sectors to improve economic development.

Likewise, according to Sudira (2018), because the need for working skills in the XXI century is quite complex and leads to the use of high order thinking skills (HOTS), then vocational learning at SMK is contextual learning related to the world of work, authentic with a technological-scientificsocio-cultural approach. According to the Minister of Education and Culture of the Republic of Indonesia that quoted by Roseno and Wibowo (2019), of all indicators of the success of any curriculum, the employment status of vocational education graduates are the main thing, so there must be continuous periodic curriculum improvement Pontillas (2018), to align with rapidly changing trends and technologies.

The Ministry of Industry of the Republic of Indonesia also recognizes this, plans to overhaul the education curriculum by stressed more on STEAM (Science, Technology, Engineering, the Arts, dan Mathematics) (Hartarto, 2018). In addition, according to Bialik et al. (2015), in the industrial era 4.0, learning is expected to meet the skills of the 21st century and able to bring together nongovernmental organizations, jurisdictions, academic institutions, corporations, and non-profit organizations, including foundations, by having four dimensions of education, namely knowledge, skills, character, and metacognition (Ref. Figure 3).

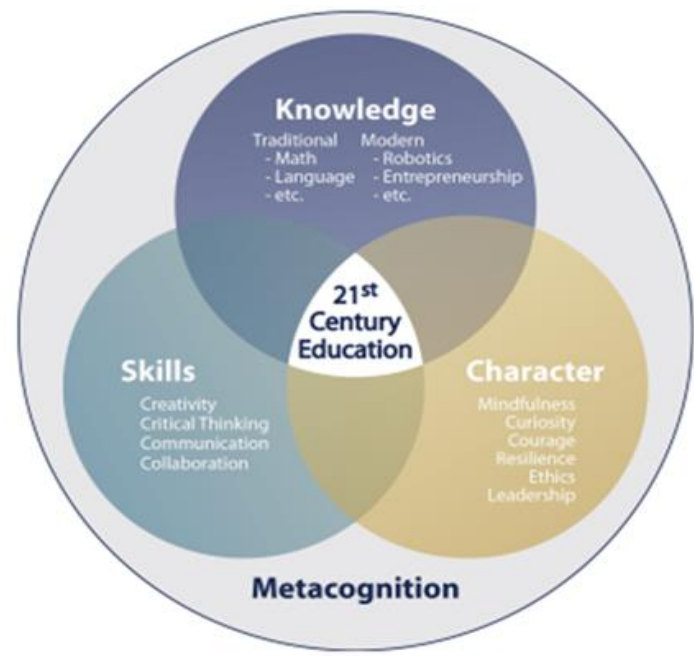

Figure 3. A Holistic Approach to The $21^{\text {st }}$ Century Curriculum

(Source: Bialik et al. (2015) 
As UNESCO (United Nations Educational, Scientific and Cultural Organization) formulated, about the concept of "the four pillars of education" (Haryono, 2006) (Ref. Figure 4), where learning is an effort to know (learning to know), do something (learning to do), living together as the basis for participating and cooperating with others in the whole activity of human life (learning to life together) and learn to be yourself (learning to be).

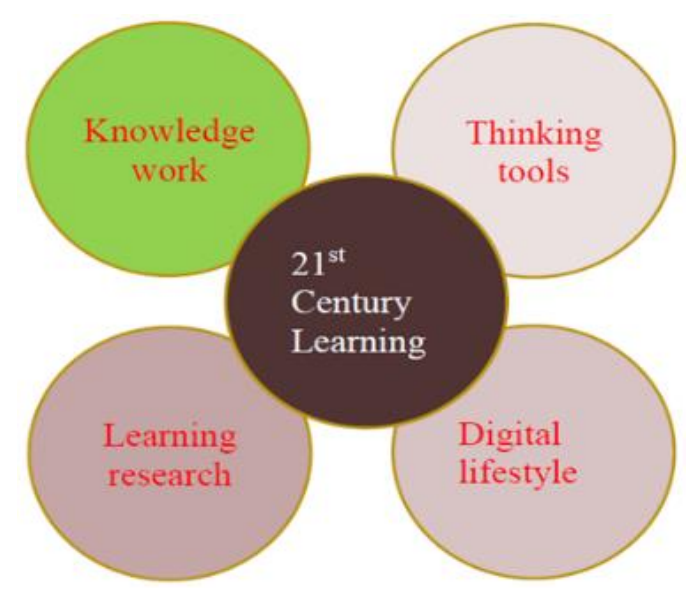

Figure 4. $21^{\text {st }}$ Century Learning

(Source: Bialik et al. 2015)

About workability, as it says Hidayah et al. (2017), there are at least ten skills. Skilled critical thinking, communication, leadership, collaboration, adaptability, productivity and accountability, innovation, global citizenship, ability and soul entrepreneurship, and the ability to access, analyze, and synthesize information. But according to Zubaidah (2016), there are seven skills. Skilled at critical thinking and problem solving, collaboration and leadership, dexterity and adaptability, initiative and entrepreneur spirit, communicating effectively orally and in writing, accessing and analyzing information, and having curiosity and imagination. While according to Baur and Wee (2015), capabilities such as computing and connectivity, analytics and business intelligence, and interaction with machines such as touch interfaces and augmented reality systems, and transferring digital instructions to physical worlds such as robotics and 3-D.

As an understanding of the industrial era 4.0 (or smart industry), quoting opinions Hermann et al. (2016), which combines automation technology with cyber technologies such as data exchange in manufacturing technologies, including physical, cyber systems, Internet of Things (IoT), and cloud computing and cognitive computing, and that affects people's lifestyles and interactions (Tjandrawinata, 2016). Regarding entrepreneurial skills, according to Meredith et al. (2000) which has also been discussed in entrepreneurial workshops (Ref. Table 1) that is: 1.) Confident, like having great faith, independent, individualistic, and optimistic.; 2.) Task and results-oriented, such as needing achievement, profit-oriented, perseverance and fortitude, hard work determination, and a strong, energetic drive and initiative.; 3.) Leadership risk-takers, such as the ability to take risks, like to challenge, behave as a leader, be able to get along with others, respond to suggestions and criticisms.

Table 1. Entrepreneurial Features

\begin{tabular}{ll}
\hline \multicolumn{1}{c}{ Features } & \multicolumn{1}{c}{ Character } \\
\hline Confident & Having great faith (conviction), independent, individualistic, optimistic \\
Task and Results Oriented & $\begin{array}{l}\text { Having a need for achievement, profit-oriented, perseverance and } \\
\text { fortitude, determination of hard work, has a strong, energetic drive and } \\
\text { initiative. } \\
\text { The ability to take risks, like to challenge. Behave as a leader, be able to } \\
\text { get along with others, respond to suggestions and criticisms. }\end{array}$ \\
\hline
\end{tabular}

(Source: Meredith et al., 2000) 
These are a number of explanations that serve as the background for this research. The reason for the selection of SMKN 7 Tangerang Regency as a research location is: 1.) SMK has been designated as a network of first-party professional certification bodies (LSP P1) in the environment SMK, based on the Decision of the Director of SMK Directorate General of Primary and Secondary Education Ministry of Education and Culture of the Republic of Indonesia No. 2583/D5.6/KP/2019 (Direktur Pembinaan SMK Republik Indonesia, 2019); 2.) Have five competencies of expertise at most in Tangerang Regency; and 3.) It has been designated as a vocational school that has the potential to be developed into a referral vocational school (Guru, 2016), based on the Decision of the Director of Coaching of SMK Directorate General of Primary and Secondary Education of Minister of Education and Culture of the Republic of Indonesia No. 705/D5.2/KP/2016.

So if the graduates of SMKN alone are difficult to get a job and can not afford to be entrepreneurial, especially other vocational school graduates whose ranks are below SMKN 7 Tangerang Regency. But if on the other hand, the interdependence scheme of communication between teachers, students, parents, LSP Accessors, and Entrepreneurs that they apply can be used as an example (role model) education communication in other vocational high schools. Theoretically, this research is beneficial for the development of communication science and relationships (relationship) in the group communication order for educational communication science. While practically speaking, this research can be a useful evaluation and input tool for SMKN 7 Tangerang Regency and other similar vocational schools. Also, of course, for professional certification bodies as well as the Ministry of Education and Culture, as a consideration in finding solutions for educational communication at SMK level such as for its graduates to have work and entrepreneurial skills.

According to Yusuf (2010), educational communication is a communication process and activity explicitly designed for the purpose of increasing added value for the target party, which is actually in many ways to improve literacy in many areas of nuanced technology, communication, and information. While according to Braslasu (2015), educational communication uses a form of didactic communication intended to transfer certain content to produce learning actions, using a complex and complete didactic communication process, which integrates verbal, nonverbal, and verbal communication.

This issue became important because: 1.) Having a clear purpose, which is also the priority and novelty in this study is, the known model, quantity percentage, and factors that affect the effectiveness of communication interdependence between teachers, parents, accessors, and entrepreneurs affecting the work and entrepreneurial skills of vocational high school students (SMKN 7 Tangerang Regency in Industrial Era 4.0) (Ref. Table 4., Table 5., Graphics 1-6., and Figure 7. \& 11.); 2.) As a way to overcome the high unemployment rate of vocational school graduates in Indonesia in the industrial era $4.0 ; 3$.) To influence education and relationship communication policies and systems in the world of vocational education.

As described by Luhmann (2001) in the theory of the social system, communication is a fundamental element for all human activity (society produced) processes, including in Educational Institutions at the vocational school level, both as a means of transferring knowledge and innovation, as well as for motivating and building human resources, which of course also benefits students' job and entrepreneurial abilities. These are a number of explanations that become the background for conducting this research, which is expected to also influence policies and educational communication systems, and relationships in vocational education at the vocational level.

\section{RESEARCH METHOD}

This type of research is a case study, comparative explanatory. Based on the elaboration of the three system theories. The Theory of the Bertalanfy school system, Shawn Fanning's Open System theory (1999) (Deny, 2018), and the Theory of the social system of the Luhmann school. This research using a positivistic paradigm (deductive logic) quantitative methods. The population is students of grade XII Vocational High School (SMK) Negeri 7 Tangerang Regency. Numbering 596 people, randomly selected (simple random sampling) based on available sampling (availability 
sampling) (Alwi, 2012). The sample number of respondents is 239 people. How to determine the number of samples, using Taro Yamane formula (Kriyantono, 2006). Taro Yamane formula can be seen in Formula 1.

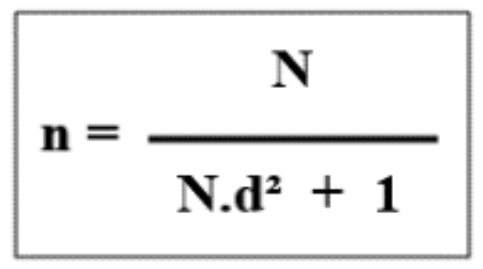

For variable measurement, the Likert scale technique is used, as a measuring tool for attitudes, opinions, and perceptions, with a category of responses (Ref. Table 2.): highly effective (HE), effective (E), quite effective (QE), less effective (LE), and ineffective (I). Score with Likert Scale can be seen in Table 2.

Table 2. Score by Likert Scale

\begin{tabular}{cc}
\hline Statement & Score \\
\hline Highly Effective (HE) & 4 \\
Effective (E) & 3 \\
Quite Effective (QE) & 2 \\
Less Effective (LE) & 1 \\
Ineffective (I) & 0 \\
\hline
\end{tabular}

As a primary data collection technique, a closed questionnaire is used, which is analyzed with the Statistical Package for the Social Sciences (SPSS) program version 24. To measure the degree of relationship between variables used Correlation Pearson Product Moment. The hypothesis was tested with a t-test at a significant level ( $\dot{\alpha}) 0,05$ one-way. The decision to accept or reject the zero hypotheses $(\mathrm{Ho}$ ) or working hypothesis $(\mathrm{Ha})$ by comparing the $\mathrm{t}$-count with the $\mathrm{t}$-Table with the limit if the $\mathrm{t}$-count is $\leq$ the $\mathrm{t}$-Table or significant value (sig.) $\geq 0,05$, ho was accepted, and Ha was rejected. Conversely, if $\mathrm{t}$-count $\geq \mathrm{t}$-Table or significant value (sig.) $\leq 0,05$, ho was rejected, and Ha was accepted. To test data validity, used validity tests, reliability tests, normality tests, $r$ tests, T-tests, and $\mathrm{F}$ tests. Validity test (validity) uses product-moment correlation technique for continuum data, especially interval data, because it uses Likert scale, by comparing the correlation results $r$ count by $\mathrm{r}$ table, with significance value $<0.05$ means invalid, and if the value of the $>0.05$, then valid.

Reliability test uses an internal consistency approach, with formulas Cronbach's Alpha. The basis of decision-making as explained by Sugiyono (2013), if $\alpha$ positive and $\alpha$ more than r-Table, then the reliable instrument, and if the $\alpha$ positive and $\alpha$ less than r-Table, the instrument is not reliable. Next, if $\alpha$ negative and $\alpha$ more than r-Table, then the instrument is not reliable, and if $\alpha$ negative and $\alpha$ less than r-Table, then the instrument is not reliable. As for the value of tolerance, $r$ Table or r-Alpha is 0,6 . So when the reliability test result value is more or equal to 0,6 , then the reliable instrument. To make calculation easy, using SPSS 24.

As for the results of Test $F$ (Ref. Table 3.) known that: 1.) The significance values for the influence of X1a, X2a, X3a, X4a, and X5a on Y1 are $0.000<0.05$ and the value of F count 673.017 $>\mathrm{F}$ so that it can be concluded there is a simultaneous influence of X1a, X2a, X3a, X4a and X5a on $\mathrm{Y} 1$.; and 2.) The significance values for the influence of X1b, X2b, X3b, X4b, and X5b on Y2 are $0.000<0.05$ and the value of $\mathrm{F}$ count $179.385>\mathrm{F}$ so that it can be concluded there is a simultaneous influence of X1b, X2b, X3b, X4b and X5b on Y2. (Ref. Table 3.) 
Table 3. T-test Result

\begin{tabular}{|c|c|c|}
\hline No. & Variables Connection & Result \\
\hline 1 & $\begin{array}{l}\text { The effectiveness of communication interdependence between teachers } \\
\text { and students affecting the work skills of vocational high school students } \\
\text { (SMKN } 7 \text { Tangerang Regency in Industrial Era 4.0) }\end{array}$ & $\begin{array}{r}\text { Ha rejected } \\
\text { (ineffective) }\end{array}$ \\
\hline 2 & $\begin{array}{l}\text { Communication interdependence between students affecting the } \\
\text { effectiveness of the work skills of vocational high school students } \\
\text { (SMKN } 7 \text { Tangerang Regency in Industrial Era 4.0) }\end{array}$ & $\begin{array}{l}\text { Ha accepted } \\
\text { (effective) }\end{array}$ \\
\hline 3 & $\begin{array}{l}\text { The effectiveness of communication interdependence between parents } \\
\text { and students affecting the work skills of vocational high school students } \\
\text { (SMKN } 7 \text { Tangerang Regency in Industrial Era 4.0) }\end{array}$ & $\begin{array}{l}\text { Ha rejected } \\
\text { (ineffective) }\end{array}$ \\
\hline 4 & $\begin{array}{l}\text { The effectiveness of communication interdependence between accessors } \\
\text { and students affecting the work skills of vocational high school students } \\
\text { (SMKN } 7 \text { Tangerang Regency in Industrial Era 4.0) }\end{array}$ & $\begin{array}{l}\text { Ha rejected } \\
\text { (ineffective) }\end{array}$ \\
\hline 5 & $\begin{array}{l}\text { The effectiveness of communication interdependence between } \\
\text { entrepreneurs and students affecting the work skills of vocational high } \\
\text { school students (SMKN } 7 \text { Tangerang Regency in Industrial Era 4.0) }\end{array}$ & $\begin{array}{l}\text { Ha accepted } \\
\text { (effective) }\end{array}$ \\
\hline 6 & $\begin{array}{l}\text { The effectiveness of communication interdependence between teachers } \\
\text { and students affecting the entrepreneurial skills of vocational high school } \\
\text { students (SMKN } 7 \text { Tangerang Regency in Industrial Era 4.0) }\end{array}$ & $\begin{array}{l}\text { Ha accepted } \\
\text { (effective) }\end{array}$ \\
\hline 7 & $\begin{array}{l}\text { The effectiveness of communication interdependence between students } \\
\text { affecting the entrepreneurial skills of vocational high school students } \\
\text { (SMKN } 7 \text { Tangerang Regency in Industrial Era 4.0) }\end{array}$ & $\begin{array}{l}\text { Ha accepted } \\
\text { (effective) }\end{array}$ \\
\hline 8 & $\begin{array}{l}\text { The effectiveness of communication interdependence between parents } \\
\text { and students affecting the entrepreneurial skills of vocational high } \\
\text { school students (SMKN } 7 \text { Tangerang Regency in Industrial Era 4.0) }\end{array}$ & $\begin{array}{l}\text { Ha accepted } \\
\text { (effective) }\end{array}$ \\
\hline 9 & $\begin{array}{l}\text { The effectiveness of communication interdependence between accessors } \\
\text { and students affecting the entrepreneurial skills of vocational high } \\
\text { school students (SMKN } 7 \text { Tangerang Regency in Industrial Era 4.0) }\end{array}$ & $\begin{array}{l}\text { Ha rejected } \\
\text { (ineffective) }\end{array}$ \\
\hline 10 & $\begin{array}{l}\text { The effectiveness of communication interdependence between } \\
\text { entrepreneurs and students affecting the entrepreneurial skills of } \\
\text { vocational high school students (SMKN } 7 \text { Tangerang Regency in } \\
\text { Industrial Era 4.0) }\end{array}$ & $\begin{array}{c}\text { Ha accepted } \\
\text { (effective) }\end{array}$ \\
\hline
\end{tabular}

\section{RESULT AND DISCUSSION}

\section{Result}

Vocational HIGH SCHOOL (SMKN) 7 Tangerang Regency is an industrial technology, engineering, and tourism school. Have seven skills or competency programs. There are Mechanical Expertise Competencies (Machining Engineering), Automotive Engineering Competencies (Light Vehicle Engineering), Tourism Expertise Competencies (Hospitality Accommodation), Accounting Competencies, and Gourmet Competence and there is Motorcycle Engineering Competency, and the latest is Multimedia Competency, which is started in 2019. SMKN 7 Tangerang Regency is located in a strategic environment, near Dasana Indah Housing complex, surrounded by shopping, trade, higher education, industrial, and residential areas. Established on May 12th, 2008, inaugurated in February 2009, by the Department of Education and Culture of the Republic of Indonesia, ISO Certificate 9008-2008 by PT. MSA Certification Cert. No. KorQ-120991, and NSS: 40-1-28-04-28004, NPSN : 20614509

This school vision is to make SMKN 7 Tangerang Regency a professional education and training institution with national standards in realizing competence, competitiveness, independence, noble, and religion. Also has a mission that is: 1.) Develop skills and precision excellence; 2.) Apply discipline and honesty based on the spirit of God; 3.) Develop care for others and the environment 
in learning activities; 4.) Teaching and learning activities (KBM) optimally oriented to standards; 5.) Increase the quantity and quality of cooperation with business and industry and other institutions in 2013. The school is quite well known. In addition to being often the best vocational school in Tangerang Regency, also known as the only vocational school in Tangerang Regency with seven competencies of expertise at once, and the only SMKN with the skills competencies of Hospitality and Food Accommodation. Already accredited "A" for light vehicle engineering, hospitality accommodation, machining engineering, and accredited "B" for Accounting. Even in 2008, SMKN 7 Tangerang Regency already have ISO 9001 certificate from PT BSC Certification, upgraded back in 2015. SMKN 7 Tangerang Regency has had LSP P1 from BNSP since 2017 for light vehicle engineering, machining engineering, hospitality accommodation, and accounting competencies. Based on 2019-2020 school data, the number of students at SMKN is 1926. The number of educators is 21 teachers who are civil servants, and 42 teachers are honorary. Assisted by 24 honorary Administrative staff.

From the results of the survey through questionnaires on 239 respondents, it was known that the effectiveness of interdependence of communication teachers, parents, accessors, and entrepreneurs on the work skills of vocational high school students (SMKN 7 Tangerang Regency in Industrial Era 4.0), varies (Ref. Table 4.): 1.) The effectiveness of teacher communication interdependence is more effective on students' psychomotor skills than on students' affective, cognitive, and metacognitive skills; 2.) The effectiveness of interdependent communication between students is more effective for students' metacognition skills than on students' psychomotor, affective, and cognitive skills; 3 .) The effectiveness of the interdependence of parental communication is more effective for students' affective skills than on students' psychomotor, cognitive, and metacognitive skills; 4.) The effectiveness of the communication interdependence of the assessors was more effective on the students' affective skills than on the students' methanogenic, cognitive, and metacognitive skills; and 5.) The effectiveness of entrepreneurs' interdependency is more effective for students' metacognitive skills than on students' psychomotor, affective, and cognitive skills.

Table 4. The Effectiveness of Communication Interdependence Teachers, Parents, Accessors, and Entrepreneurs Affecting The Work Skills of Vocational High School Students (SMKN 7 Tangerang Regency in Industrial Era 4.0)

\begin{tabular}{cll}
\hline No. & Communication Interdependence & \multicolumn{1}{c}{ Effectiveness of Students Work Skills } \\
\hline 1 & Between teacher and students & Most effective against psychomotor abilities \\
2 & Between students & Most effective on students metacognity capabilities \\
3 & Between parents and students & Most effective at affective ability \\
4 & Between accessors and students & Most effective at affective ability \\
5 & Between entrepreneurs and & Most effective on students metacognity capabilities \\
\hline
\end{tabular}

Likewise, the effectiveness of communication interdependence teachers, parents, accessors, and entrepreneurs affecting the entrepreneurial skills of Vocational High School Students (SMKN 7 Tangerang Regency in Industrial Era 4.0) also varies, as can be seen in Table 5: 1.) The effectiveness of teacher communication interdependence is more effective on student leadership skills than on students 'ability to complete assignments and students' self-confidence (Similar to the results of Doctoral Dissertation from Nam, (2008)); 2.) The effectiveness of interdependent communication between students is more effective for students 'leadership skills than on students' self-confidence and ability to complete assignments (Similar to the results of Doctoral Dissertation from Corral (2018)); 3.) The effectiveness of parental communication interdependence is more effective on the student's skills to complete the task than on the student's self-confidence and leadership skills (a reference to the theoretical components of parental empowerment) (Hsiao et al., 2018); 4.) The assessors' communication interdependence effectiveness was more effective on the student's selfconfidence than the student's skills to complete assignments and the student's leadership skills.; and 5.) Entrepreneurs' communication interdependence effectiveness is more effective on student leadership skills than on students' self-confidence and ability to complete assignments. 
Table 5. The Effectiveness of Communication Interdependence Between Teachers, Parents, Accessors, and Entrepreneurs Affecting The Leadership Skills of Vocational High School Students

(SMKN 7 Tangerang Regency in Industrial Era 4.0)

\begin{tabular}{cll}
\hline No. & Communication Interdependence & \multicolumn{1}{c}{ Effectiveness of Students Leadership Skills } \\
\hline 1 & Between teacher and students & Most effective against leadership skills \\
2 & Between students & Most effective on students leadership capabilities \\
3 & Between parents and students & Most effective at completing students skills \\
4 & Between accessors and students & Most effective at students confidence skills \\
5 & Between entrepreneurs and students & Most effective on students leadership capabilities \\
\hline
\end{tabular}

\section{Discussion}

According to Bartalanfy in his system theory, in each organization, there is interconnectedness between its parts, known as "interdependency." The same is the case in the education system in SMKN 7 Tangerang Regency. It is known that there is the interdependence of teacher communication, such as communication knowledge, communication skills, communication behavior, and emotion of teacher communication, which is effective against psychomotor, affective, cognitive, and metacognition skills, as the work skills of vocational high school students (SMKN 7 Tangerang Regency in Industrial Era 4.0) (Ref. Figure 5 until Figure 9)

According to Bukit (2014), vocational education must be able to answer industry challenges 4.0., must have characteristics that are oriented towards individual performance in the world of work, specific justifications on real needs in the field, and the focus of the curriculum must be on psychomotor, affective, and cognitive aspects, as well as benchmarks of success not only limited in schools, but must also have sensitivity to the development of the world of work, thus requiring adequate means and infrastructure, and the support of the community.

Same like SMKN 7 Tangerang Regency, vocational high school education was also assessed to have an effect on the psychomotor, affective, cognitive, even metacognition abilities of its pupils (Ref. Figure 5 until Figure 9) (highly effective (HE), effective (E), quite effective (QE), less effective (LE), dan ineffective (I)). Although admittedly, some hypotheses are rejected. Such as the communication interdependence of teachers, parents, and accessors, which is considered ineffective on the work skills of vocational high school students (SMKN 7 Tangerang Regency in Industrial Era 4.0). Nevertheless, it still influences (Ref. Figure 5, Figure 6, Figure 7, Figure 8, Figure 9).

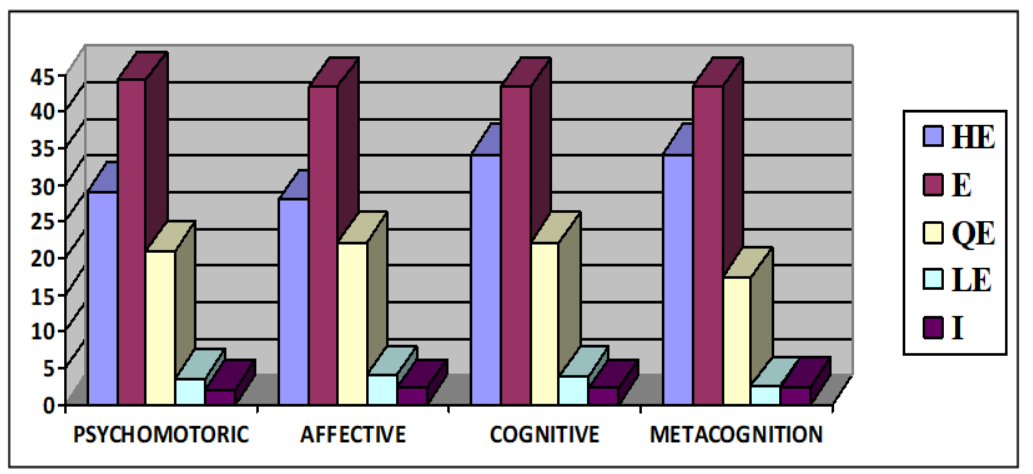

Figure 5. The Effectiveness of Communication Interdependence Between Teachers and Students Affecting The Work Skills of Vocational High School Students (SMKN 7 Tangerang Regency in Industrial Era 4.0) 


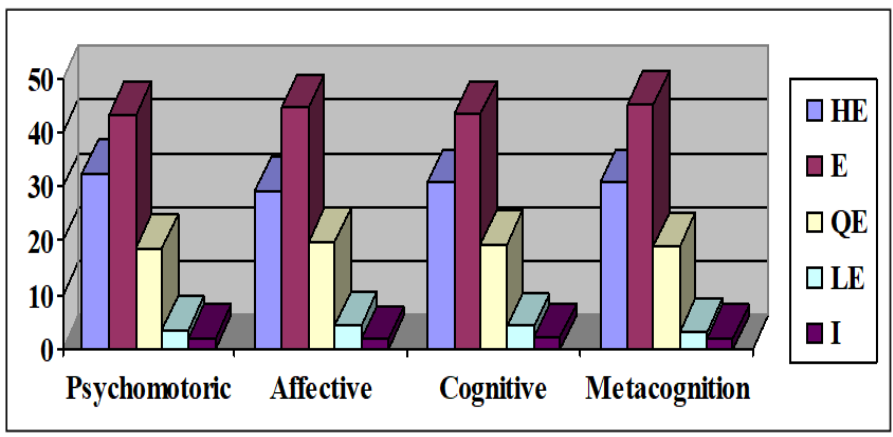

Figure 6. The Effectiveness of Communication Interdependence Between Students Affecting The Work Skills of Vocational High School Students (SMKN 7 Tangerang Regency in Industrial Era 4.0)

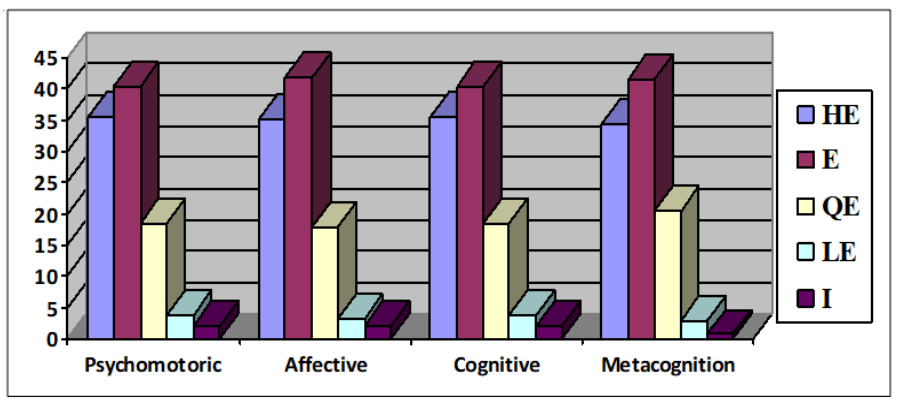

Figure 7. The Effectiveness of Communication Interdependence Between Parents and Students Affecting The Work Skills of Vocational High School Students (SMKN 7 Tangerang Regency in Industrial Era 4.0)

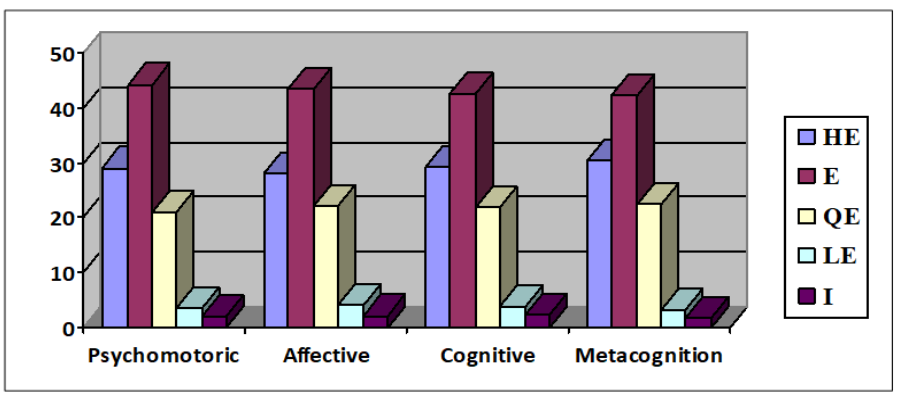

Figure 8. The Effectiveness of Communication Interdependence Between Accessors and Students Affecting The Work Skills of Vocational High School Students (SMKN 7 Tangerang Regency in Industrial Era 4.0)

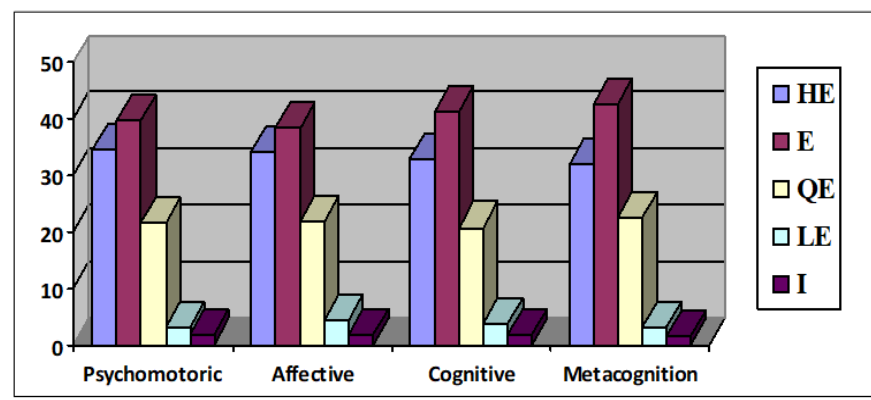

Figure 9. The Effectiveness of Communication Interdependence Between Entrepreneurs and Students Affecting The Work Skills of Vocational High School Students (SMKN 7 Tangerang Regency in Industrial Era 4.0) 
Thus, the majority of communication interdependence in the education system in vocational high school students (SMKN 7 Tangerang Regency in Industrial Era 4.0) has an influence on the psychomotor, affective, cognitive, and metacognition skills of its students, which is useful as a work skill in the industrial era 4.0. In addition, for vocational high school students (SMKN 7 Tangerang Regency in Industrial Era 4.0), communication interdependence between students as well as entrepreneurs is much more effective than interdependence of communication of teachers, parents, and accessors of the work skills of students, in the era of industry 4.0. Other things about the entrepreneurial skills of vocational high school students (SMKN 7 Tangerang Regency in Industrial Era 4.0). As for the entrepreneurial skills, as said by Meredith et al. (2000), which has also been discussed in entrepreneurial workshops (Ref. Table 1 which has also been discussed in entrepreneurial workshops). In addition to having confidence, being oriented to tasks and results, also have leadership skills.

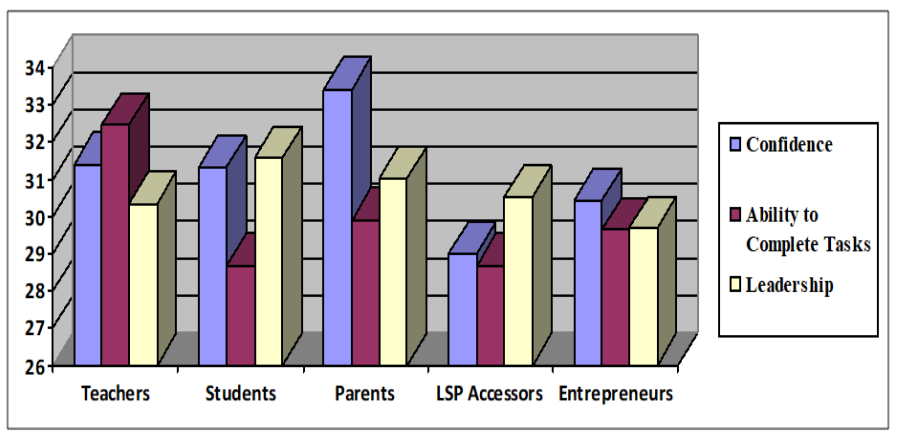

Figure 10. The Effectiveness of Communication Interdependence Between Teachers, Parents, Accessors, and Entrepreneurs Affecting The Entrepreneurial Skills of Vocational High School Students (SMKN 7 Tangerang Regency in Industrial Era 4.0)

Similarly, in this school, the majority of communication interdependence in the school education system is considered effective for students' confidence, as well as the ability to complete tasks, and student leadership, which is beneficial as the entrepreneurial skills of students in the industrial era 4.0 (Ref. Figure 10). So there is only one hypothesis rejected, namely the interdependence of accessor's communication towards students' entrepreneurial skills, which is considered ineffective. However, that doesn't mean it doesn't have any effect at all (Ref. Figure 10).

In the end, it is understandable, for vocational high school students (SMKN 7 Tangerang Regency in Industrial Era 4.0), namely (Ref. Figure 11.): 1.) The communication interdependence between teachers, parents, students, and entrepreneurs more affecting the entrepreneurial skills of vocational high school students than with the accessors; 2 .) The education communication system in vocational high school (SMKN 7 Tangerang Regency in Industrial Era 4.0), not yet 100\% effective on the work and entrepreneurial skills of Vocational High School students (Ref. Table 3.), partly because of the interdependence of teacher communication to the work skills of students in the industrial era 4.0. rated still ineffective; 3.) The communication interdependency between students and the entrepreneurs is considered $100 \%$ effective, both towards work and entrepreneurial students in the industrial era $4.0 ; 4$.) Many factors influence the effectiveness of the communication interdependence between teachers, parents, accessors, and entrepreneurs affecting the work and entrepreneurial skills of vocational high school students (SMKN 7 Tangerang Regency in Industrial Era 4.0) (Ref. Figure 11.); 5.) There are synergies and complementary relationships in communication interdependence in the communication system of vocational high school students (SMKN 7 Tangerang Regency in Industrial Era 4.0), which affects its students' work and entrepreneurial skills (Ref. Figure 11.). 


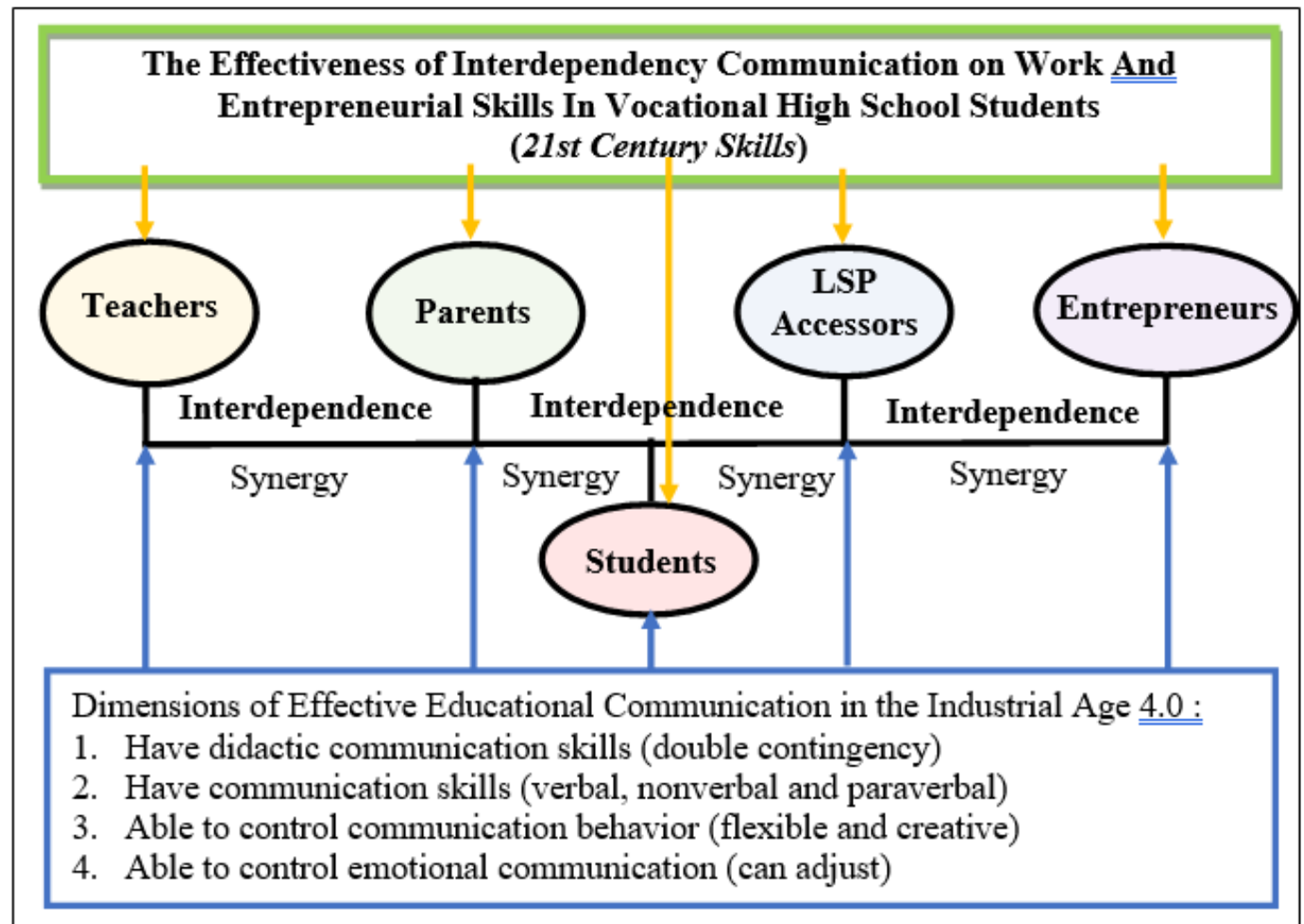

Figure 11. Model of The Effectiveness of Communication Interdependence Between Teachers, Parents, Accessors, and Entrepreneurs Affecting The Work and Entrepreneurial Skills of Vocational High School Students (SMKN 7 Tangerang Regency in Industrial Era 4.0)

\section{CONCLUSION}

In the end, it was obtained as follows, which at the same time can be an evaluation and input for SMKN 7 Tangerang Regency, and another vocational high school, as well as the Ministry of Education and Culture of the Republic of Indonesia, namely: 1.) The effectiveness of communication interdependence between teachers, students, parents, accessors, and entrepreneurs has a different effect on vocational high school students' work and entrepreneurial skills in the industrial era $4.0 ; 2$. Interdependence of communication between students and Entrepreneurs at SMKN 7 Tangerang Regency is rated $100 \%$ effective on its students' work and entrepreneurial skills; 3.) LSP Accessors communication interdependence, which has been done, is rated $100 \%$ ineffective on the work and entrepreneurial skills of vocational high school students (SMKN 7 Tangerang Regency) in the Industrial Era 4.0; 4.) The school's education communication system is considered not yet 100 effective on its students' work and entrepreneurial skills, so it is likely that many graduates from the school are not ready for work and entrepreneurship. So the education communication system in this school is not yet $100 \%$ worthy of being a role model for other vocational schools, but can still be used as a reference as a comparison and alternative policy options; and 5.) Many factors affect the effectiveness of educational communication interdependence in this school, and all of these factors create communication interdependency that has different effectiveness to work and entrepreneurial skills of vocational high school students (SMKN 7 Tangerang Regency) in Industrial Era 4.0 (Ref. Figure 11.).

\section{ACKNOWLEDGMENTS}

Thanks to: 1.) Higher Education Service Institute of Region III Jakarta and Ministry of Education and Culture of the Republic of Indonesia, grant stipends (SK, No. 7/E/KPT/2019 and Agreement/Contract No. 02-5/027/HK-SPK/III/2019); 2.) Universitas Mercu Buana Research Center; and 3.) SMKN 7 Tangerang Regency. 


\section{REFERENCES}

Alwi, I. (2012). Kriteria empirik dalam menentukan ukuran sampel pada pengujian hipotesis statistika dan analisis butir. Formatif: Jurnal Ilmiah Pendidikan MIPA, 2(2), 140-148. https://doi.org/10.30998/formatif.v2i2.95

Baur, C., \& Wee, D. (2015). Manufacturing's next act. McKinsey \& Company. https://www.mckinsey.com/business-functions/operations/our-insights/manufacturingsnext-act\#

Bialik, M., Fadel, C., Trilling, B., Nilsson, P., \& Groff, J. (2015). Skills for the 21 st century: What should students learn? https://curriculumredesign.org/wp-content/uploads/CCRSkills_FINAL_June2015.pdf

Braslasu, M. (2015). Aspects of didactic communication in primary school. Procedia - Social and Behavioral Sciences, $180, \quad 497-501$. https://doi.org/https://doi.org/10.1016/j.sbspro.2015.02.150

Bukit, M. (2014). Strategi dan inovasi pendidikan kejuruan: Dari kompetensi ke kompetisi. Alfabeta.

Corral, J. (2018). The impact of a peer-teaching instructional approach on a student's selfconfidence [University of South Carolina]. https://www.proquest.com/openview/4653015278eba778f13c60be68cb522c/1?pqorigsite $=$ gscholar $\& \mathrm{cbl}=18750 \&$ diss $=\mathrm{y}$

Deny, S. (2018, March 11). Miris, pengangguran terbanyak justru dari SMK. Liputan 6. https://www.liputan6.com/bisnis/read/3362702/miris-pengangguran-terbanyak-justru-darismk

Direktur Pembinaan SMK Republik Indonesia. (2019). SK Penetapan SMK Sebagai Jejaring LSPP1. http://smk.kemdikbud.go.id/konten/4248/sk-penetapan-smk-sebagai-jejaring-lsp-p1

Guru, B. (2016). SMK rujukan sebagai pusat SMK unggulan dan efektif. Direktorat Sekolah Menengah Kejuruan. Kementerian Pendidikan Dan Kebudayaan Republik Indonesia. https://smk.kemdikbud.go.id/konten/1496/smk-rujukan-sebagai-pusat-smk-unggulan-danefektif

Hartarto, A. (2018). Making Indonesia 4.0. http://www.kemenperin.go.id/download/18384

Haryono, H. (2006). Model pembelajaran berbasis peningkatan keterampilan proses sains. Jurnal Pendidikan Dasar, 7(1), 1-13. http://blog.unnes.ac.id/fransharyono/wpcontent/uploads/sites/2969/2017/06/MODEL-PEMBELAJARAN-BERBASISPENINGKATAN-KETERAMPILAN-PROSES-SAINS.pdf

Hermann, M., Pentek, T., \& Otto, B. (2016). Design principles for industrie 4.0 scenarios. 2016 49th Hawaii International Conference on System Sciences (HICSS), 3928-3937. https://doi.org/10.1109/HICSS.2016.488

Hidayah, R., Salimi, M., \& Susiani, T. S. (2017). Crictical thinking skill: Konsep dan indikator penilaian. Taman Cendekia: Jurnal Pendidikan Ke-SD-An, 1(2), 127-133. https://doi.org/10.30738/tc.v1i2.1945

Hsiao, Y.-J., Higgins, K., \& Diamond, L. (2018). Parent Empowerment: Respecting Their Voices. TEACHING Exceptional Children, 51(1), 43-53. https://doi.org/10.1177/0040059918790240

Kriyantono, R. (2006). Teknik praktis riset komunikasi. Kencana Prenada Media Group.

Luhmann, N. (2001). Soziale Systeme: Grundriß einer allgemeinen Theorie. Suhrkamp; Neuauflage.

Meredith, G. G., Neck, P. A., \& Nelson, R. E. (2000). Kewirausahaan teori dan praktek (D. Suseno (ed.)). Pustaka Binaman Pressindo. 
Nam, C. W. (2008). The relative effectiveness of positive interdependence and group processing on student achievement, interaction, and attitude in online cooperative learning [Texas A\&M University].

https://www.proquest.com/openview/270a9272dde2c0c6cb3326ec02202f75/1?pqorigsite $=$ gscholar\&cbl $=18750$

O'Hair, D., Friedrich, G. W., \& Dixon, L. D. (2009). Strategic communication in business and professions (6th ed.). Kencana Prenada Media Group.

Pontillas, V. V. (2018). Tracer study on bachelor of science in electrical engineering graduates of a polytechnic college in the Philippines from 2007 to 2010. Asia Pacific Journal of Multidisciplinary Research, 6(2), 36-46. https://d1wqtxts 1 xzle7.cloudfront.net/62371039/APJMR-2018.6.2.2.0520200315-130496123g310.pdf?1584271242=\&response-content-

disposition=inline\%3B+filename\%3DTracer_Study_on_Bachelor_of_Science_in_E.pdf\& Expires $=1627629568 \&$ Signature $=Q 8 A M s l j F U t a T l q s 8 n r 3 U f J C 67$

Rawi, M. A. Bin. (2013). Leadership on technical and vocational education in community college. Journal of Education and Practice, 4(21), 21-23. https://www.iiste.org/Journals/index.php/JEP/article/view/8267

Ritzer, G., \& Goodman, D. J. (2008). Teori sosiologi: Dari teori sosiologi klasik sampai perkembangan mutakhir tori sosial postmodern. Kreasi Wacana.

Roseno, I., \& Wibowo, U. B. (2019). Efisiensi eksternal pendidikan kejuruan di Kota Yogyakarta. Jurnal Akuntabilitas Manajemen Pendidikan, 7(1), 15-24. https://doi.org/10.21831/amp.v7i1.10558

Sudira, P. (2018). Metodologi pembelajaran vokasional abad XXI: Inovasi, teori, dan praksis (1st ed.). UNY Press.

Sugiyono, S. (2013). Metode penelitian pendidikan: Pendekatan kuantitatif, kualitatif, dan $R \& D$ (17th ed.). Alfabeta.

Tjandrawinata, R. (2016). Industri 4.0: revolusi industri abad ini dan pengaruhnya pada bidang kesehatan dan bioteknologi. In Working Paper of Dexa Medica Group. https://doi.org/10.5281/zenodo.49404

Yusuf, P. M. (2010). Komunikasi instruksional teori dan praktik. Bumi Aksara.

Zubaidah, S. (2016). Keterampilan abad ke-21: Keterampilan yang diajarkan melalui pembelajaran. Seminar Nasional Pendidikan, 10(2), 1-17. https://www.researchgate.net/profile/SitiZubaidah-7/publication/318013627_KETERAMPILAN_ABAD_KE21_KETERAMPILAN_YANG_DIAJARKAN_MELALUI_PEMBELAJARAN/links/595 4c8450f7e9b2da1b3a42b/KETERAMPILAN-ABAD-KE-21-KETERAMPILAN-YANGDIAJARKAN-MELALUI-PEMBELAJARAN.pdf 